\title{
Association of Blastocystis subtype 3 and 1 with patients from an Oregon community presenting with chronic gastrointestinal illness
}

Morris S. Jones • Christopher M. Whipps •

Robert D. Ganac • N. Ryan Hudson • Kenneth Boorom

Published online: 10 January 2009

(C) Springer-Verlag 2009

Erratum to: Parasitol Res

DOI 10.1007/s00436-008-1198-7

The original version of this article unfortunately contained a mistake. The spelling of the Kenneth Boorom's name was incorrect.

The online version of the original article can be found at http://dx.doi.org/10.1007/s00436-008-1198-7.

M. S. Jones $(\bowtie) \cdot$ R. D. Ganac $\cdot$ N. R. Hudson

Clinical Investigation Facility,

David Grant USAF Medical Center,

101 Bodin Circle, Travis AFB,

Fairfield, CA 94535, USA

e-mail: drmorrisj@yahoo.com

C. M. Whipps

Department of Microbiology, Oregon State University,

Nash Hall 220,

Corvallis, OR 97331-3804, USA

\section{K. Boorom}

Blastocystis Research Foundation, 5060 Philomath Boulevard, \#202,

Corvallis, OR 97333, USA 